\title{
Identification of point mutations in Glucose-6-Phosphate Dehydrogenase gene in Timor Island people : A preliminary report
}

\author{
Widanto Hardjowasito ${ }^{*}$, Bambang Pardjianto ${ }^{*}$, Loeki Enggar Fitri ${ }^{*}$, Mardhani Ys ${ }^{*}$, Loekito R.M*, \\ Taku Shirakawa\#, Kaoru Nishiyama", Masafumi Matsuo \#
}

\begin{abstract}
Abstrak
Defisiensi enzim glukosa 6 fosfat dehidrogenase (G6PD) umumnya ditemukan di daerah endemis malaria, namun sampai sekarang tidak ada satu pun penelitian tentang dasar molekuler defisiensi G6PD di daerah Pulau Timor Indonesia yang merupakan daerah hiperendemik malaria dengan mayoritas penduduk dari ras Proto Malay. Untuk mengetahui frekuensi dan tipe mutasi secara molekuler, seratus delapan belas penduduk asli Timor diperiksa menggunakan tes Formazan ring untuk penentuan defisiensi G6PD. Mutasi pada G6PD gene ditentukan dengan metode MPTP (Multiple PCR Using Multiple Tandem Forward primers and a common reserve Primer) dan konfirmasi dilakukan dengan automatic sequencer. Tiga penduduk laki-laki menunjukkan aktivitas G6PD yang rendah dan dengan MPTP dua di antaranya menunjukkan adanya mutasi noktah. Sekuensing dari dua kasus tersebut berhasil mendeteksi adanya mutasi pada T383C pada exon 5 dan C592T pada exon 6 . Kesimpulan dari penelitian ini adalah telah ditemukan mutasi noktah pada exon 5 dan exon 6 dari gen G6PD penderita ras Proto Malay. Dua jenis mutasi ini merupakan mutasi yang umum ditemukan di daerah Asia. (Med J Indones 2001; 10: 210-3)
\end{abstract}

\begin{abstract}
Glucose 6 phosphate dehydrogenase (G6PD) deficiency is common in malaria endemic region, however no molecular study has been performed on G6PD deficiency in Timor Island, Indonesia, a malarial hyperendemic area which Proto Malay is the majority of the people in that island. To observe the frequency and molecular type of mutations in G6PD deficient Proto Malay people, 118 native people were screened using formazan ring test. Mutation in the G6PD gene were determined by MPTP (Multiple PCR using Multiple Tandem Forward Primers and a common Reserve Primer) method and confirmed by automatic sequencer. This study shows that three males have lower G6PD activity. Using MPTP method, a point mutation could be indicated in the two cases. Sequencing of the amplified products in 2 G6PD patients disclosed mutations of T383C in exon 5 and C $592 \mathrm{~T}$ in exon 6 in respective case. Our result documents point mutations in exon 5 and exon 6 in the G6PD gene of two Proto Malay people in Timor. These mutations are common in Asia region. (Med J Indones 2001; 10: 210-3)
\end{abstract}

Keywords: mutations, G6PD, Proto Malay.

Glucose 6 Phosphate Dehydrogenase (G6PD) deficiency, an $\mathrm{X}$ chromosome linked hereditary enzymopathy, is the most common red cell abnormality of humans. ${ }^{\prime}$ This disease entity is caused by the inheritance of any of large number of abnormal alleles of the gene

* Congenital Anomalies and Growth Studies Section, Biomedical Research Center, Medical Faculty, Brawijaya University, Malang, Indonesia

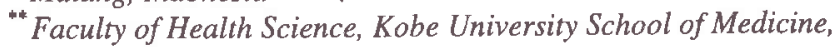
Tomogaoka, Suma, Kobe, Japan

" Division of Genetics, International Center for Medical research, Kobe University, School of Medicine, Kusunokicho, Chuo, Kobe, Japan responsible for the synthesis of the G6PD molecule. Majority of G6PD deficient individuals are asymptomatic but exposure to fava beans, certain drugs such as the anti malarial drug like primaquin and infections may trigger a variety of clinical manifestation ranging from acute hemolytic anaemia to severe chronic non spherocytic hemolytic anaemia. ${ }^{2,3}$ It is a globally important cause of neonatal jaundice and causes lifethreatening hemolysis crisis in children. It is common in Mediterranean, African and some East Asian population but rare in Korea. Only four cases of G6PD deficient have been first noticed in Korea. ${ }^{4}$

In addition, many cases of silent mutations in the gene have also been discovered. Virtually all mutations 
except some deletions of 3 or 9 bases are single base substitutions in the coding region. There is evidence that the high frequencies of deficient alleles have arisen because they cover a selective advantage against malaria. ${ }^{5}$

Several studies on frequency and the genetic basis of G6PD deficiency among the Deutro Malay racial group are published. ${ }^{6}$ However, no information is available for the Proto Malay racial group living in East Nusa Tenggara Timur Province of Indonesia (NTT) where malaria is still highly endemic.

To facilitate clarification of the molecular basis of G6PD deficiency, Shirakawa et $\mathrm{al}^{7}$ has developed a multiplex PCR method using multiple tandem forward primers and a common reverse primer (MPTP method). This simple method facilitates molecular study of G6PD deficiency, especially in developing countries.

The aim of this study is observe to the frequency and molecular type of mutations in G6PD deficient Proto Malay people. One hundred eighteen native Proto Malay people were screened using formazan ring test. Two unrelated patients of G6PD deficiency were' studied for its nucleotide change in exons 5 and 6 of the G6PD gene by MPTP. Here, we demonstrate two mutations T383C and C592T of the G6PD gene in Proto Malay Indonesians.

\section{METHODS}

Blood samples from 118 independent Proto Malay were randomly collected on filter in July 1998 in sub district Insana, district Kefamenanu, Timor Island, Province of Nusa Tenggara Timur.

G6PD deficiency was screened by using the Formazan ring method. Mutation scanning was performed in the G6PD gene using MPTP developed by Shirakawa et al. ${ }^{7}$ MPTP was carried out by the hot start PCR method. Ten microlitres of solution containing $8 \mu \mathrm{l}$ of master mixture (10 mM Tris-HCl, $\mathrm{pH} 8,3 ; 10 \mathrm{mM} \mathrm{KCl}$; 250 umM dNTPs; 2,5 mM MgCl2 dan 5\% DMSO), 1 ul of the primer mixture, $1 \mu \mathrm{l}$ of the enzyme mixture $(0,9 \mu \mathrm{l}$ of distilled water and $0,1 \mu \mathrm{l}$ of $5 \mathrm{U}$ Ampli taq DNA Polymerase Stoffel Fragment Perkin Elmer Co, USA) were preheated to $85^{\circ} \mathrm{C}$. PCR was then carried out with the following cycles : 25 cycles at $95^{\circ} \mathrm{C}$ and $72^{\circ} \mathrm{C}$ and $\mathrm{O}^{\circ} \mathrm{C}$ for 30 second each. The products were run in 4\% agarose gel electrophoresis (MetaPhor/ Seaken HGT 3:1) containing $0,5 \mu \mathrm{g} / \mathrm{ml}$ ethidium bromide and the gels were photographed using a UV transluminator. All exons of the G6PD gene were then amplified from DNA samples and was subjected to direct sequencing using a dye terminator kit (Perkin Elmer Co), an automatic DNA sequencer (AB PRISM 310), Genetic Analyser (Perkin-Elmer Co).

\section{RESULT}

G6PD deficiency is common in malaria endemic regions and is estimated to affect upwards of 400 million people world-wide. To date, more than 300 different G6PD variants have been distinguished on the basis of biochemical parameters, suggesting a vast genetic heterogeneity. ${ }^{1}$ So far, however, only a small portion of this heterogeneity has been confirmed at the DNA level through the identification of about 60 different mutations in the G6PD coding sequence. ${ }^{8}$ A mutant G6PD enzyme may be different from person to person, mutation can be in the form of point mutation or can range from one to several base pair deletions as well as replacements in the DNA. ${ }^{9}$ Different populations have different types of mutations, but within a specific population, common mutations are usually shared. In Southeast Asia mutation in exon 5, 6 and 9 are common.

Two patients with G6PD deficiency and one patient with low enzyme activity were detected from 118 Proto Malay individuals by the formazan ring test. We examined mutations in exon 5 and exon 6 of the G6PD gene in two patients. One patient was found to have a $\mathrm{T}>\mathrm{C}$ substitution at nucleotide position 383 in exon 5 (Fig 1). This mutation corresponds to the variant G6PD Banks and Torres (Vanua lava). The other patient was found to have $\mathrm{a} C>\mathrm{T}$ substitution in exon 6 at position 592 and corresponds to the variant Coimbra (Fig 2) respectively. These substitutions were confirmed by the nucleotide sequencing procedure. However, we could not identify any mutation in the patient with low enzyme activity.

\section{DISCUSSION}

Our result indicated that mutation screening in the limited number of exons of the G6PD gene has succeeded to identify mutations in the Proto Malay 
Indonesians, even though Proto Malay has been considered as an isolated population in the NTT region. This suggested that Proto Malay is not isolated but mixed up with other Indonesian, since both G6PD Banks and Torres (Vanua Lava) and G6PD Coimbra have been identified in other parts of Indonesia. However, it needs further study to get a conclusion. G6PD Coimbra is included in the "Mediterranean Type" which are characterized by decreased Michaelis constant $(\mathrm{Km})$ for both G6P and NADP and low substrate specificity. ${ }^{10}$

Our result showed that MPTP scanning mutation in exons 5 and 6 are useful to characterized molecular background in Proto Malay G6PD deficiency. The usefulness has been confirmed not only in Singapore but also in Philippines. ${ }^{11,12}$ Since MPTP needs only PCR machine, this technique could be employed in South East Asia countries to characterized mutations. Another method using SSCP (Single-Strand Conformation and Sequence Analysis) had been used to identify genetic heterogeneity in Calabria. ${ }^{13}$

Among 118 Proto Malay Indonesians in Timor Island, two males were found to have a point mutation. One of them has a point mutation in exon 5 corresponding to the variant G6PD Banks and Torres and the other in exon 6 corresponding to the variant Coimbra.

Further studies are planned in the same region this year. A bigger population would be investigated, which also includes malaria cases. The need for utilizing screening measures for early detection of the genetic defect is immediately apparent, once consideration is taken of the high probability of association of G6PD deficiency with other hemoglobinopathies, such as sickle cell anaemia, which may lead to a more serious condition. In addition, there is a compelling need for introducing measures such as genetic counselling and public health education as part of the overall health and welfare services in the area.

\section{Acknowledgement}

We gratefully acknowledge the permission and encouragement from Dr Bambang Purnomo, Kakanwil Kesehatan RI Propinsi NTT, Drs Anton Amaunut, Bupati KDH TTU and Dr Valentinus Parrera Kadinkes TTU Propinsi NTT, for this study.

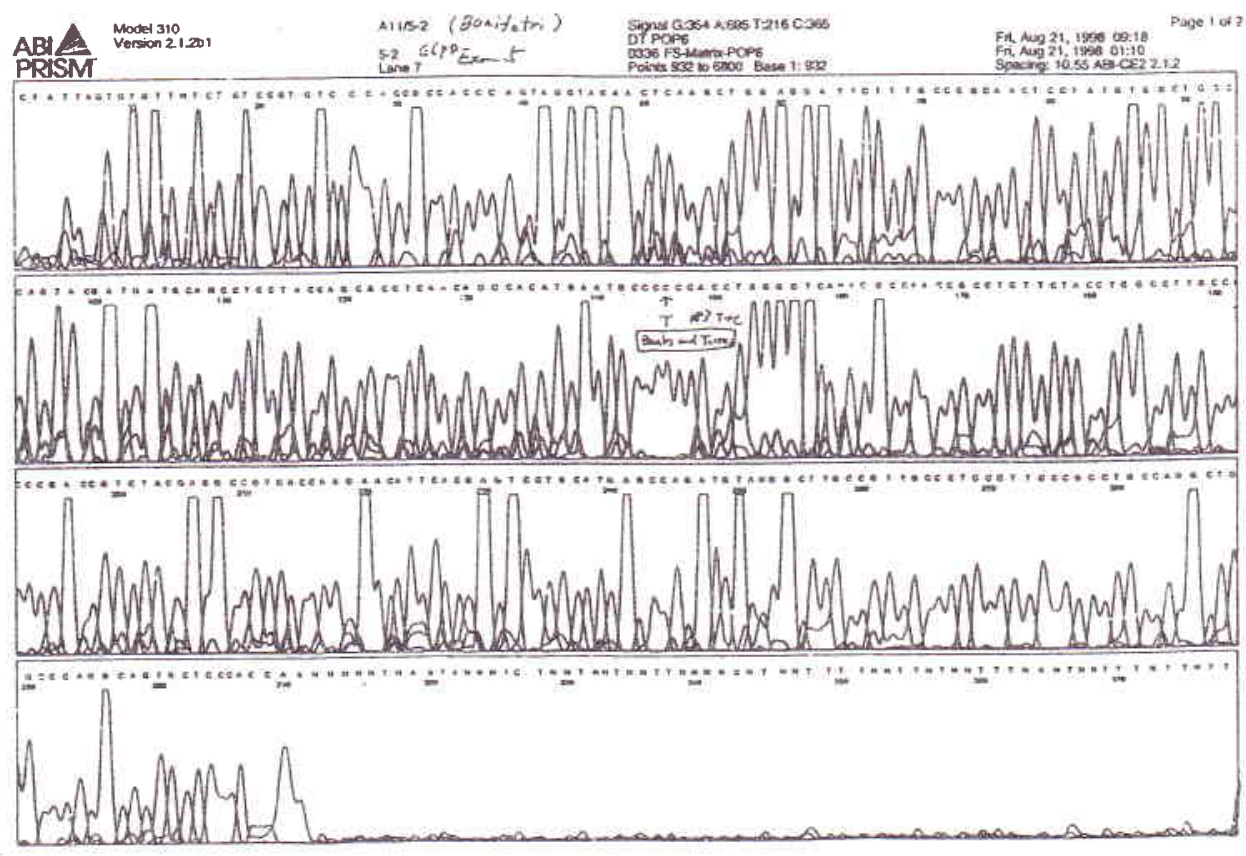

Figure 1.

Sequencing of one patient with G6PD deficiency. He was found to have a $T>C$ substitution at nucleotide position 383 in exon 5. This mutation corresponds to the variant G6PD Banks and Torres (Vanua lava). 


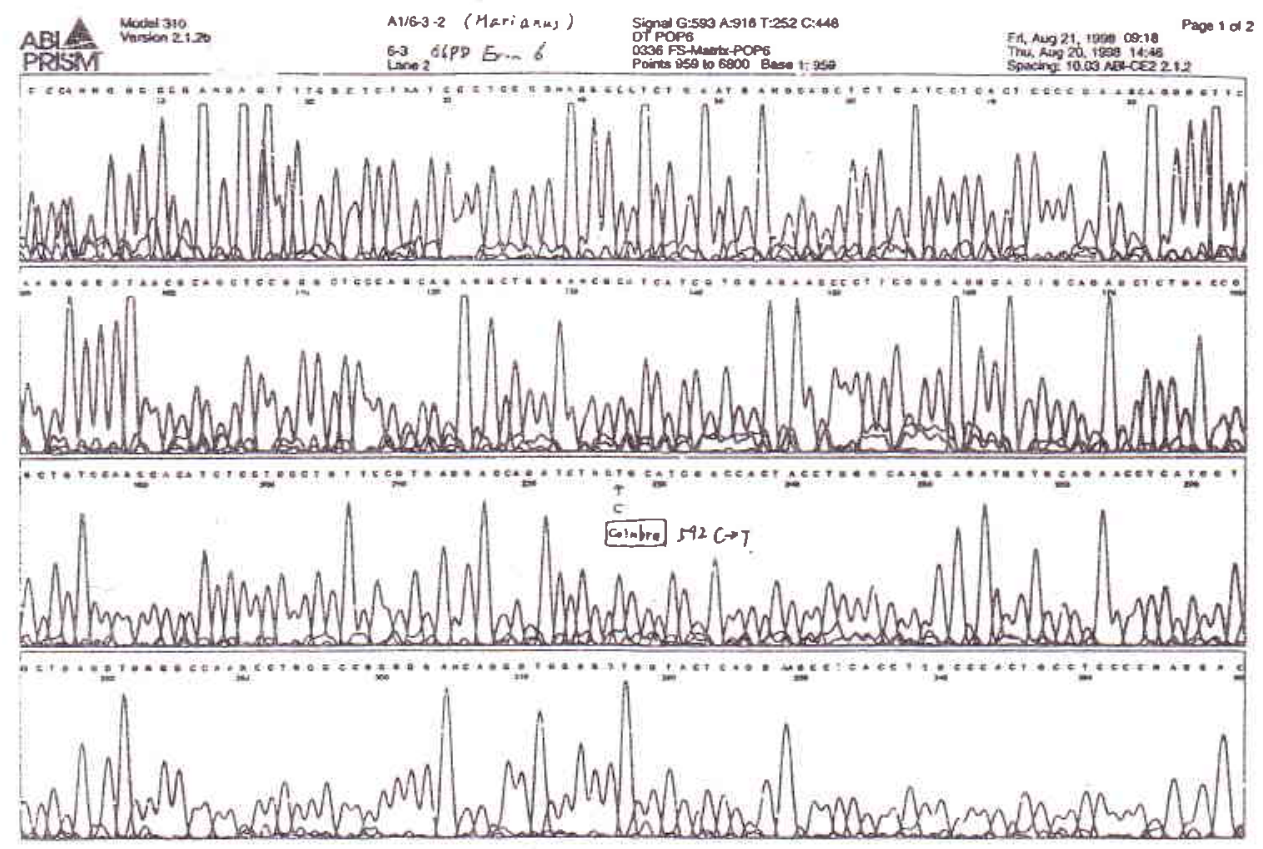

Figure 2.

Sequencing of one patient with G6PD deficiency. He was found with a $C>T$ substitution in exon 6 at position 592 and corresponds to the variant Coimbra.

\section{REFERENCES}

1. Beutler E. G6PD deficiency. Blood 1994; 84: 3613-36.

2. Beutler E, Kuhl W. The NT 1311 Polymorphism of G6PD: G6PD Mediterranean mutation may have originated independently in Europe and Asia. Am J Hum Genet $1990 ; 47 ; 1008-12$.

3. Mason $P$. New insight into G6PD deficiency. Br J Haematol 1996 ; 94:585-91.

4. Kim M.K., Yang-CH, Kang S.H.,Lyu-CJ, Kim-KY. Glucose -6 phosphate dehydrogenase deficiency-report of 4 cases. J Korean Med Sci.1992; 7(1):71-5.

5. Ruwende C, Khoo SC, Snow RW. Natural selection of hemi- and heterozygotes for G6PD deficiency in Africa by resistance to severe malaria, Nature, $1995 ; 376: 246-49$

6. Rovira A, Vulliamy TJ, Pujades MA, Luzzatto L, Corrons JLV. The Glucose- 6 phosphatase dehydrogenase (G6PD) deficient variant G6PD union (454 Arg-Cys) has aworldwide distribution possibly due to recurrent mutation. Human Mol. Gen. 1994; 3 633-835.

7. Shirakawa T, Nishiyama K, Lai Poh-San, Matsuo M. A comprehensive Method to scan for point mutation of the Glucose 6 Phosphatase Dehydrogenase. Jpn J Human Genet 1997; 42:417-23.
8. Ganczakowski M, Town M, Bowden DK, Vulliamy TJ, Kaneko A, Clegg JB, Weatherall DJ, Luzzato L. Multiple glucose-6-phosphate dehydrogenase deficient variants correlate with malaria endemicity in Vanuatu Archipelago (Southwestem pacific). Am J Hum Genet 1995; 56:294301.

9. Scriver CR. Glucose-6-phosphate Dehydrogenase Deficiency. In: The metabolic and molecular bases of inherited disease. 1995; McGraw- Hill $7^{\text {th }}$ edition: 3367-98.

10. Corcoran CM, Calabro V, Tamagnini G, Town M, Haidar B, Vulliamy TJ, Mason PJ, Luzzato L. Molecular heterogeneity underlying the G6PD Mediterranean phenotype. Hum Genet 1992; 88: 688-90

11. Fujii $\mathrm{H}$, Takahashi $\mathrm{K}$, Miwa $\mathrm{S}$. A new simple screening method for glucose-6-phosphatase dehydrogenase deficiency, Acta Haematol Jpn 1984; 47:185-8

12. Hsia YE, Miyakama F, Baltazar L. Frequency of Glucose6-phosphate dehydrogenase deficiency (G6PD) mutation in Chinese, Filipinos, and Laotians from Hawaii. Jpn J Human Genet 1993; 92:470-76.

13. Calabro v, Mason PJ, Filosa SD. Genetic heterogeneity of Glucose-6-phosphate dehydrogenase deficiency revealed by single-strand conformation and sequence analysis, Am J Hum Genet 1993, 52:527-36. 